\title{
CIVIL PATRIOTISM GROUPS IN REGIONAL COMMUNITIES IN THE SOUTH OF RUSSIA
}

\author{
Anna V. Vereshchagina ${ }^{1 *}$, Anatoly V. Lubsky ${ }^{2}$, Yuriy G. Volkov ${ }^{3}$, Ilya V. Pechkurov ${ }^{4}$, Yakov A. Aslanov ${ }^{5}$ \\ $1^{*}, 2,3,4,5$ Institute of Sociology and Regional Studies, Southern Federal University, Rostov-on-Don, Russia. \\ Email: 1*anrietta25@mail.ru, ${ }^{2}$ __lav@mail.ru, ${ }^{3}$ ugvolkov@ @fedu.ru, 4i.pechkurov@gmail.com, ${ }^{5}$ aslanov@sfedu.ru
}

Article History: Received on $23^{\text {rd }}$ March 2020, Revised on $24^{\text {th }}$ May 2020, Published on $21^{\text {st }}$ June 2020

\begin{abstract}
Purpose: The purpose of the article is to study groups of civil patriotism and to highlight the features of their civilPatriotic practices in local communities in the South of Russia.

Methodology: The sociological investigation utilized quantitative and subjective strategies, just as techniques for hypothetical understanding of the acquired experimental information. The basis of the scientific study of common nationalism bunches in Russia in the South of Russia was a lot of wellsprings of experimental data, including the aftereffects of a sociological report directed by an individual poll "up close and personal" in five subjects of the Russian Federation in the South of Russia.

Result: The results of the sociological study made it possible to distinguish two social groups in regional communities youth and the "over 60" generation, which are currently the social basis for the development of civic patriotism, whose representatives are characterized by a desire for active social action for the good of the fatherland and its people, participation in civil practices aimed at protecting social interests, civil rights and freedoms, as well as readiness for civil liability for their deeds and actions both in the field of professional activity and in everyday life.
\end{abstract}

Applications: This research can be used for universities, teachers, and students.

Novelty/Originality: The results of a sociological study show that in local communities in the South of Russia, no more than $10 \%$ of the population can be classified as civil patriotism groups.

Keywords: Patriotism, State Patriotism, Civil Patriotism, Civil Practices, Regional Communities, Youth, Generation "over 60".

\section{INTRODUCTION}

Russian society has recently been offered patriotism as a national idea of a unifying principle, which is positively perceived by most Russians, including in local communities in the South of Russia. At the same time, most Russians consider patriotism as one of the most significant human qualities associated with love to the Motherland and willingness to defend it. However, Russian patriotism, which causes a complex of positive feelings among Russians, is still lacking, as researchers note, citizenship, that is, people's aspirations to actively participate in the affairs of society and the state, the desire of people to change the situation in the country, providing it with a decent future (Faleeva et al., 2017; Volkov et al., 2018a,b; Gafiatulina et al., 2019; Gorbunov et al., 2019).

Thus, according to the results of sociological research, $13 \%$ of Russians find "willingness to participate in solving common affairs", and to take "responsibility for what is happening in the country" - only $3 \%, 11 \%$ listed to their three main dreams a desire to be useful to society, to contribute to the development of the country (Gorshkova, 2016). This is due, on the one hand, to the specifics of the etatism-paternalistic mentality of Russians (Lubsky et al., 2016b), and on the other, to the insufficient development of civil society in Russia and the lack of grassroots civil subjectivity.

However, the level of civil activity of various social groups is gradually growing in Russian society, and civil-patriotic practices are struggling, but are making their way through the thickness of state patriotism. In this regard, the study of civil patriotism groups and civil-patriotic practices in local communities in southern Russia is acquiring special scientific and practical significance.

The aftereffects of a sociological report show that in neighborhood networks in the South of Russia, close to $10 \%$ of the populace can be named common enthusiasm gatherings. Thus, certain aspects of patriotism and citizenship, patriotic and civil practices in the southern Russian regions have already been considered in the scientific literature. However, the groups of civil patriotism were not studied and the peculiarities of their civil-patriotic practices in local communities in the South of Russia were not distinguished.

Therefore, the aim of this research is to examine gatherings of common enthusiasm and to feature the highlights of their common Patriotic practices in nearby networks in the South of Russia.

\section{REVIEW OF LITERATURE}

The scientific literature has already examined various aspects related to the study of patriotism and citizenship, patriotic and civil practices in regional communities in the South of Russia (Lubsky et al., 2018; Baibarin, Mashkin, and Shelengovskiy, 2016). The focus of the researchers were primarily issues such as the impact of citizenship on the formation of patriotism among Muslim youth in the North Caucasus (Koichuev, 2013), positive practices and risks of 
citizenship in youth environment (Shulga and Kuznetsov, 2014; Podymov et al., 2019), civil patriotism and youth consolidation (Shevchenko and Vagina, 2017), citizenship deficit in the patriotic consciousness of the population in regional communities (Vereshchagina, 2018; Kuznetsova et al., 2018; Makarova et al., 2019), social health of youth in the context of migration processes in Russia (Gryshai et al., 2018; Ponomarev, et al., 2019). In this regard, the scientific literature raises the question of the possibility of overcoming the deficit of citizenship in Russian patriotism and the prospects for the development of civil patriotism in Russian society (Lubsky, 2019).

A general diagram for another Israeli reflection on the idea of a comprehensive common enthusiasm and instruction for energy was offered that endeavored to change a run of the mill energetic language from an oppositional language into a language of solidarity and comprehensiveness (Gusacov, E. 2018). The nature and typology of enthusiasm, its existential, political, recorded, legendary, and strict grounds were considered (Kugay, A. I. 2018).

Talks of the nationalism in Russia speak to introductions of its examination brings about the system of such logical controls, as theory, history, political theory, human science, and brain research. Inside the structure of these controls, the enthusiasm was considered, considering different paradigmatic inclinations, first, ontological, axiological, recognizable proof and social substance (Volkov, Y. G., et.al. 2018). Resurgent enthusiasm for the assurances gave in the Malaysian Federal Constitution and to comprehend the rights-based language utilized by Malaysian common society entertainers in the course of recent years was contended (Khoo, G. C. 2014).

Williams, R. L., Foster, L. N., \& Krohn, K. R. (2008) found that both productive and visually impaired energy were essentially identified with proportions of basic speculation, regard for common freedoms, and accentuation on national security yet in contradicting bearings. The technique that Historical memory has been strengthened by the present system's instructive socialization through the national "Enthusiastic Education Campaign" after 1991 was considered (Wang, Z. 2008). The convenience of the summed up bunch predominance point of view in clarifying the impacts of some sociodemographic factors on nationalism was illustrated (Ishio, Y. 2010).

Some help for keeping up calculated contrasts among visually impaired and representative enthusiasm was advertised (Parker, C. S. 2010). The bay between the famous view of the Witnesses as poor residents, especially during the center many years of the twentieth century, and the general public's own portrayal of its individuals as advantages for their networks features the challenged and alterable nature of the name un-American was contended (Knox, Z. 2013).

\section{METHODOLOGY}

\section{Research Methodology and Sources of Empirical Information}

The methodological difficulties associated with the study of groups of civil patriotism in local communities in the South of Russia consist of the fact that in modern scientific discourse there are different ideas about what civil patriotism is. Therefore, some researchers believe that civil patriotism is a system of values that determine the attitude of a person to society, as well as the attitude of the state to a citizen (Civil patriotism, 2019). Other researchers focus on the fact that civil patriotism as a love of the Motherland, fidelity to Russian traditions, and values is interconnected with an active life position and civil responsibility (Oborsky et al., 2018; Kolesnikov, 2013; Minakhmetova et al., 2017).

In society, one should distinguish between state, or "blind" patriotism, and civil or "constructive" patriotism (Schatz, Staub and Lavine, 1999). State patriotism associated with the normative type of national pride, which is the result of people's indoctrination, is characterized by their attachment to their homeland, its unquestioning positive assessment, and intolerance to criticism of their state (Mukhametzyanova et al., 2018; Bubnova et al., 2018; Cherdymova et al., 2018). Civil patriotism associated with the rational type of national pride implies the willingness of people who are aware of the organic belonging to their homeland to take active and responsible social actions for the good of the fatherland, as well as their desire to make their personal contribution to the development of society and change the situation in the country for the better as part of a critical attitude towards social reality (Kolesnikova and Lubsky, 2018).

In accordance with this, civil-patriotic practices in local communities can be considered as various repertoires of social actions related to individual or collective social activity of citizens aimed at solving problems of socially significant interest (Shakhbanova et al., 2019). However, one can distinguish formal civil-patriotic practices supported from above by state authorities and stipulated by regulatory legal acts, and informal civil-patriotic practices that develop in the process of social communication as a result of self-organization of citizens (Lubsky and Mamina, 2019).

The basis of the scientific study of civil patriotism groups in the South of Russia was a set of sources of empirical information, including the results of a sociological study conducted by the face-to-face survey in five regions of the Russian Federation in the South of Russia (Rostov Region, Stavropol Territory, Republic of Adygea, Kabardino-Balkar Republic and the Republic of Crimea), which made it possible to identify the ideas of various youth groups about civil patriotism as values and attitudes of social behavior. Besides, the results of an expert survey of representatives of state and municipal authorities, scientific and educational institutions, public and non-profit organizations, youth associations, and the media conducted in various regions of the Russian Federation in the South of Russia were used.

The sociological study used quantitative and qualitative methods, as well as methods of theoretical interpretation of the obtained empirical data. 


\section{RESULTS AND DISCUSSION}

The results of a sociological study conducted in local communities in the South of Russia indicate that about $77 \%$ of respondents consider themselves patriots. Moreover, for the vast majority (67.8\%) of them, ideas about patriotism are associated with emotional-sensory connotations: love for the Motherland (24.7\%), willingness to defend it (23.3\%) and a sense of the inextricable connection of a person with his country, its culture, and history (19.8\%). However, only $8.9 \%$ of the population of the South Russian regions can be directly attributed to groups of civil patriotism in local communities. Moreover, citizenship in the perception of patriotism is most characteristic of the age cohort "over 60 years," since $27.5 \%$ of its representatives perceive patriotism as an activity aimed at the benefit of society and the country. At the same time, the perception of citizenship in this age group is weakly correlated with civil activity, and therefore representatives of this cohort do not show much desire to participate in civil practices.

The civil component of patriotism to a certain extent is also characteristic of representatives of the age group "from 41 to 50 years". Among them, 23.5\% of respondents preferred the perception of patriotism as activities related to the protection of the rights, interests, and freedoms of citizens of the country. This position turned out to be less significant for those who are "from 51 to 60 years old". Patriotism for this age group is, first of all, a deep feeling of love for the Motherland (63.1\%) and a willingness to defend the Motherland and its people (55.1\%). To an even lesser extent, civil patriotism is characteristic of young people $(16.6 \%)$, who are more civil than other age groups. This is since civil practices in the minds of young people are in no way "linked" to patriotic ideas, values, and attitudes.

The results of a sociological study showed the dependence of the level of civil patriotism of various groups of youth in the South of Russia on one or another of its social and sociodemographic characteristics (gender, place of residence, type of professional employment). Thus, civil patriotism turned out to be more characteristic of the male part of youth living in cities, as well as young military personnel and administrative workers.

In general, as evidenced by the results of sociological research, in youth environment in all regions of the South of Russia prevail traditional ideas about patriotism as "the feeling of deep love for the Motherland" and "the feeling of an inextricable connection of a person with his country, its culture and history". Such representations are most pronounced among young people in the Republic of Crimea. Crimean youth to a greater extent identifies patriotism with a willingness to defend their homeland and their people $(51.1 \%)$, which is associated primarily with the events of the Crimean spring and the rise in the republic of youth patriotism of a heroic sovereign-romantic type. In this regard, the Crimean youth demonstrates an insignificant level of civil patriotism $(7.8 \%)$.

Citizenship in the perception of patriotism is more pronounced among the youth of the Republic of Adygea (35.3\%), the Rostov region (20.0\%), and the Stavropol Territory (15.8\%). The high rate of civil patriotism among the youth of the Republic of Adygea is due to the fact that their young people tend to interpret patriotism as a national idea uniting the Russian people in order to achieve common goals and jointly solve important social problems (52.9\%).

The distribution of respondents' answers in all age cohorts by occupation showed that patriotism as an activity aimed at protecting the rights and freedoms of citizens is perceived to a greater extent by military personnel, self-employed, representatives of the middle administrative personnel of enterprises and organizations, employees of the administration and pensioners. Wherein, the same respondents surveyed are more likely to be willing to defend their homeland.

The analysis of sociological data on the type of activity in certain regions in the South of Russia showed that the civil perception of patriotism is more characteristic of the military personnel of Stavropol, Crimea, and Adygea, the selfemployed of Stavropol, Rostov region and Adygea, administrative workers of the Rostov region and Crimea. In the Kabardino-Balkarian Republic, the special significance of the civil component in patriotism is characteristic of employees, retirees, and homemakers.

The results of the sociological study also showed the dependence of the level of civil patriotism on the financial situation of respondents: it was high among those who rated their financial situation as good (25.4\%), and low among those who rated their financial situation as poor $(15,8 \%)$. For them, as compared to the other respondents, more typical is the idea of the "manipulative essence" of patriotism as a means of influencing public consciousness on the part of the authorities (16.2\%). Among respondents with a good and satisfactory attitude to their financial situation, this position was the least popular (10.9\% and $7.4 \%$, respectively). The same dependence can be observed regarding the level of education: respondents with higher education are more oriented to the values of civil patriotism.

The results of a sociological study were tested in a survey of experts, who characterizing patriotism in the regions of the South of Russia, noted a weak expression in it of civil attitudes related to social activity, social responsibility, and a critical attitude to reality. Wherein, experts among the factors hindering the development of civil patriotism identified, firstly, the dominance in the minds of Russians of the impossibility of ordinary citizens to influence the social situation and managerial decisions in regions and municipalities (17.2\%), secondly, the presence of excessive social inequalities that form an acute sense of social injustice and social apathy among the population (15.7\%), and thirdly, the lack of development of civil society institutions in the country $(13.8 \%)$.

As for civil patriotism in the youth environment, its development is hindered, as experts note, primarily by factors such as the unresolved vital issues of youth in education, employment, creation and support of the family (19.7\%), insufficient 
consideration of opinions and interests of young people themselves in the practice of civil-patriotic education (17.0\%), the absence in the educational programs of secondary and higher education of courses focused on the formation of citizenship (13.1\%), low confidence of young people in state and municipal authorities in the regions (11.2\%), as well as the inconsistency of actions of state authorities, NGOs and educational institutions in organizing civil patriotic practices among young people $(9.7 \%)$.

Wherein, experts as the main agent of influence on the formation of civil patriotism among the youth singled out the education, and then the state and family (Vereshchagina and Gafiatulina, 2016). Among the factors in the education system, which, in the opinion of experts, will contribute to the development of civil patriotism in youth environment, was highlighted, firstly, closer cooperation of educational institutions with NGOs focused on solving social problems in the regions $(26.7 \%)$, active involvement of students in the practice of civil-patriotic education and civil activities (22.5\%), creation of volunteer centers in educational institutions, their cooperation with regional and municipal authorities, NGOs, mass media, and families of students (20.9\%). The introduction of the civil education course as compulsory in the system of secondary and higher education was rated as less significant (16.8\%) compared with practice-oriented measures.

Moreover, experts drew attention to the need for state support of socially-oriented NGOs, involving youth in civilpatriotic practices, including through competitions to provide them with grants aimed at implementing relevant projects (17.7\%), improving the regulatory framework of socially oriented activities of NGOs, provision of benefits (including financial) to those who have positively proven themselves in the provision of social services and the involvement of young people in civil activities (16\%). Wherein, experts noted the need to create a unified information base in the field of development of civil initiatives, civil practices, and actions carried out jointly by NGOs, educational institutions, regional and municipal authorities (15.3\%), as well as the creation of a monitoring system for the activities of sociallyoriented NGOs with the following incentive system for those of them that most effectively contribute to the development of civil-patriotic practices among young people (13.8\%). The development of civil patriotism in the youth environment will also be promoted, as experts say, by the active cooperation of regional and municipal authorities with NGOs in order to involve young people in civil-patriotic activities related to solving social problems of local communities (15.6\%), as well as the close cooperation of NGOs with educational institutions based on the creation of "Centers for Civil Youth Initiatives" in the regions (13.9\%).

In solving problems related to the development of civil patriotism in local communities in the South of Russia, experts draw attention to the need to strengthen the role of the media related to broader coverage of civil-patriotic actions in regions and municipalities (24.1\%). It is also necessary, according to experts, to increase the role of the family in the process of civil-patriotic education of youth in educational institutions through the direct participation of adults in civilpatriotic events $(24.1 \%)$.

The theoretical interpretation of the empirical results of the sociological study of civil patriotism leads to the conclusion that the civil and patriotic values and attitudes have not yet been properly developed in local communities in the South of Russia (Gryshai et al., 2018). Therefore, no more than $10 \%$ of the population adheres to such values and attitudes. Besides, at the local level, separate groups of patriotism have already been formed, which contain the elements of citizenship in varying degrees. In this regard, on the one hand, the older generation stands out with deep traditions of state patriotism and citizenship as a civil duty, but not civil activity oriented towards civil activism and civil responsibility.

On the other hand, these are young people, who are the most, compared with other age groups, focused on the perception of citizenship as protecting the rights and freedoms of citizens, responsibility for the fate of the country, as well as critical attitude to social reality to change it for the better. In this regard, in the youth environment, there were most of all those who noted the importance of opposing the arbitrariness of the authorities, active participation in public and political life, and the ability to assert their civil rights. The All-Russian Sociological Data of All-Russian Surveys (November 2018) also indicate that every second of the young respondents is ready to join the work of public and political organizations, and every third to volunteer in order to achieve positive changes in society (Civil patriotism - the basis of the majority, 2017). However, it should be noted that civil values and attitudes in the youth environment in local communities are still weakly correlated with patriotic ideas. Therefore, in the youth consciousness, for the most part, the values and attitudes of the state rather than civil patriotism dominate. In this regard, young people, despite their higher civil activity, are not much different from the bulk of Russians, $60 \%$ of whom do not feel responsible for what is happening in the country (Responsibility and influence, 2017) due to not only their etatism-paternalistic mentality (Lubsky et al., 2016a) but also according to the reason that the state in Russia, according to a significant part of the country's inhabitants (44\%), does not fulfill its obligations to citizens (Citizens and the state, 2019).

The hypothetical translation of experimental information got over the span of a sociological report demonstrated that different gatherings of common energy have just been framed in neighborhood networks in the South of Russia, just as in Russian culture all in all. However, the proportion of such groups is insignificant, the vast majority of Russians, as the researchers note, lack a desire to make the world a better place, to fulfill their civil duty, and only $10 \%$ of the country's citizens surveyed strive for this (Gorshkova and Petukhov, 2016). 


\section{CONCLUSION}

Thus, in local communities in the South of Russia, state patriotism dominates as people's attachment to their homeland with a positive assessment of Russia and intolerance to criticism of the Russian state, especially from the outside, associated with the normative type of national pride, which does not depend on the real situation, but on people's exposure to indoctrination. In accordance with this, in the South of Russia, formal patriotic practices of a militarymobilization nature are dominated, initiated by state authorities from above, which, being part of the etatismpaternalistic mental program of social normative behavior, are sovereign. In this regard, patriotism in Russian society lacks citizenship.

The results of a sociological study show that in local communities in the South of Russia no more than $10 \%$ of the population can be attributed to groups of civil patriotism. However, if we consider this situation in the age context, it is worth noting that in the youth environment etatism-paternalistic moods are less pronounced than in other age groups. Therefore, youth more than others believes that the patriot should critically assess the situation in the country and strive to change it in order to ensure it with a decent future, as well as to combat its shortcomings and be able, to tell the truth about his country, no matter how bitter it may be. A part of the older generation, including those over 60, who are, however, displaying insignificant civil activity, also adheres to the latter position to a certain extent.

Thus, young people and this part of the older generation are currently the social base for the development of civil patriotism in Russia, the most important characteristics of which are the citizen's desire for an active individual or collective actions for the good of the fatherland and its people, civil solidarity practices aimed at protecting social interests, civil rights and freedoms, as well as the willingness of a citizen to be responsible for his affairs and actions both in the sphere of his professional activity and in everyday life.

\section{LIMITATION AND STUDY FORWARD}

This study was conducted exclusively in the south of Russia, which should be widely studied

\section{ACKNOWLEDGMENTS}

The article was made as part of the implementation of the State task (Ministry of Education and Science of the Russian Federation), project No. 28.3486.2017 / PC «Civil patriotism in the formation and development of solidaristic practices in the South of Russia: resource potential and conditions for its implementation».

\section{AUTHORS CONTRIBUTION}

Anna V. Vereshchagina and Yakov A. Aslanov developed a program and provided sociological research. Ilya V. Peckurov processed the data obtained using the SPSS program (version 23.0). Yuriy Gr. Volkov and Anatoliy V. Lubskiy analyzed the results of the conducted sociological research.

\section{REFERENCES}

1. Baibarin, A.A., Mashkin, N.A., and Shelengovskiy, P.G. (2016). The Northwest Caucasus from ancient times to the 19th century: a historiographical review of the recent publications in the periodicals. Rusin, 46(4), 119-140. https://doi.org/10.17223/18572685/46/8

2. Bubnova I.S., Khvatova M.A., Chernik V.E., Popova O.V., Prokopyev A.I., Naumov P.Yu., \& Babarykin O.V. (2018). Research of professional activity features of ecologists at carrying out the public ecological examination. Ekoloji, 106, 999-1006, Article No: e106183.

3. Cherdymova, E.I., Afanasjeva, S.A., Parkhomenko, A.G., Ponyavina, M.B., Yulova, E.S., Nesmeianova, I.A., and Skutelnik, O.A. (2018). Student ecological consciousness as determining component of the ecologicaloriented activity. EurAsian Journal of BioSciences, 12(2), 167-174.

4. Citizens and the state. (2019). Retrieved from https://www.levada.ru/2019/01/22/grazhdane-i-gosudarstvo3/print/

5. Civil activity. (2019). Retrieved from https://www.levada.ru/2019/02/13/grazhdanskaya-aktivnost/print/

6. Civil patriotism - the basis of the majority. (2017). Retrieved from http: //valyanko.livejournal.com/595.html

7. Faleeva, L.V., Bratukhina, E.V., Ezhov, S.G., Gorbunova, L.N., Lopanova, A.P., Viaznikova, L.F., and Kryukova, N.I. (2017). Student's social experience forming in university vocational training. Eurasian Journal of Analytical Chemistry, 12(7), 1127-1135. https://doi.org/10.12973/ejac.2017.00238a

8. Gafiatulina, N.Kh., Makadei, L.I., Gluzman, I.V., Lozhechkina, A.D., Volkova, L.A., and Bandurin, A.P. (2019). Integration of health-saving technologies in the process of educational and professional socialization of the Russian student-age population. International Journal of Applied Exercise Physiology, 8(2), 293-300.

9. Gorbunov, M.A., Fadeeva, A.V., Shirshikov, V.B., Matveev, P.A., Popova, O.V., Mitrofanova, M.Yu., Bakaeva, J.Yu., and Mashkin, N.A. (2019). Nature protection potential of wildlife sanctuary: Protection and preservation of its ecological biodiversity. Ekoloji, 107, 5033-5037, Article No: e107576.

10. Gorshkova, M.K. (2016). Russian society as it is: (experience of sociological diagnosis). Moscow: New Chronograph. 
11. Gorshkova, M.K., and Petukhov. V.V. (2016). Russian society and the challenges of the time. Moscow: The whole world.

12. Gryshai, V., Gafiatulina, N., Kasyanov, V., Velikodnaya, I., Kosinov, S., Lyubetsky, N., and Samygin, S. (2018). Social Health of Youth in the Context of Migration Processes in Russia: Assessment of the Threat to National Security. Вісник Національної академї керівних кадрів культури і мистеитв, 2, 141-145.

13. Gusacov, E. (2018). Education for patriotism and the Arab-Israeli sector. International Journal of Educational Development, 60, 138-148. https://doi.org/10.1016/j.ijedudev.2017.11.005

14. Ishio, Y. (2010). Social bases of American patriotism: Examining the effects of dominant social statuses and socialization. Current Sociology, 58(1), 67-93. https://doi.org/10.1177/0011392109348546

15. Khoo, G. C. (2014). The rise of constitutional patriotism in Malaysian civil society. Asian Studies Review, 38(3), 325-344. https://doi.org/10.1080/10357823.2013.767309

16. Knox, Z. (2013). Jehovah's Witnesses as Un-Americans? Scriptural Injunctions, Civil Liberties, and Patriotism. Journal of American Studies, 47(4), 1081-1108. https://doi.org/10.1017/S0021875813001369

17. Koichuev, A.A. (2011). On the problem of the study of citizenship and patriotism of Muslim youth in the North Caucasus. Islamic Studies, 1, 39-46.

18. Kolesnikov, V.A. (2013). Civil patriotism and civil political culture in modern Russia. Historical, philosophical, political and legal sciences, cultural studies, and art history. Questions of theory and practice, 3(29), 84-91. (In Russ.).

19. Kolesnikova, E.Yu, and Lubsky, A.V. (2018). Patriotism and citizenship among young people in the South of Russia: paradigms of sociological research. Humanitarian of the South of Russia, 5, 174-183.

20. Kuznetsova N.V., Soloviev A.A., Botasheva L.Kh., Lebedev I.A., Sarkisyan K.S., Kurdyumov V.I., Chistyakov K.A., and Prokopyev A.I. (2018). Bachelor's safety culture formation in the field of environmental protection. EurAsian Journal of BioSciences, 12(2), 157-166.

21. Kugay, A. I. (2018). Patriotism as a Factor of Civic Identification and National Unity. Administrative Consulting. https://doi.org/10.22394/1726-1139-2018-5-152-161

22. Lubsky, A.V. (2019). Patriotism and citizenship in Russian society, or how to overcome the deficit of citizenship in Russian patriotism. Humanitarian of the South of Russia, 2, 47-66.

23. Lubsky, A.V., and Mamina, D.A. (2019). Citizenship in the youth environment as a subject of theoretical and methodological discourse. Social and humanitarian knowledge, 7, 69-78.

24. Lubsky, A.V., Kolesnykova, E.Y., and Lubsky, R.A. (2016a). Normative Type of Personality and Mental Matrix of Social Behavior in Russian Society. Indian Journal of Science and Technology, 9(36), 1020-1023. https://doi.org/10.17485/ijst/2016/v9i36/102023

25. Lubsky, A.V., Kolesnykova, E.Y., and Lubsky, R.A. (2016b). Mental Programs and Social Behavior Patterns in Russian Society. International Journal of Environmental and Science Education, 11(16), 9549-9559.

26. Lubsky, A.V., Volkov, Yu.G., Vereshchagina, A.V., Kolesnikova, E.Yu., and Aslanov, Ya.A. (2018). Organizational and Legal Aspects of Patriotic Practices in Regional Communities in the South of Russia. International Journal of Civil Engineering and Technology, 9(11), 180-189.

27. Makarova, E.V., Kryukova, N.I., Sizova, Z.M., Grinenko, A.V., Erofeeva, M.A., and Bukalerova, L.A. (2019). Divergence of supreme values of the Russian world and western civilization social and philosophical analysis. EuropeanJournal of Science and Theology, 15(3), 97-107.

28. Minakhmetova, A.Z., Skutelnik, O.A., Fedorchuk, Y.M., Shulga, T.I., Pavlushin, A.A., and Shagiev, B.V. (2017). The motivational and valuable orientation of teachers as a condition to form students' tolerant behavior. Man in India, 97(3), 323-332.

29. Mukhametzyanova, L.Y., Aleksandrova, N.S.,Greek, A.D., Zatsepina, M.B., Prokopyev, A.I., and Gaidamashko, I.V. (2018). Culture-oriented component scientific and methodical support of students' humanitarian training in university. XLinguae, 11(1), 230-241. https://doi.org/10.18355/XL.2018.11.01.19

30. Oborsky, A.Y., Chistyakov, A.A., Prokopyev, A.I., Nikolyukin, S.V., Chistyakov, K.A., and Tararina, L.I. (2018). The national mentality in the history of philosophy. XLinguae, 11(3), 158-165.

31. Parker, C. S. (2010). Symbolic versus blind patriotism: Distinction without a difference?. Political Research Quarterly, 63(1), 97-114. https://doi.org/10.1177/1065912908327228

32. Podymov, N.A., Nikoghosyan, M.A., Stolyarova, A.N., Narutto, S.V., Mashkin, N.A., Martynenko, S.E., Paznikova, Z.I., and Varenik, P.K. (2019). University of New Educational Reality in Disruptive Technologies Context. Journal of Environmental Treatment Techniques, 7(4), 664-668.

33. Ponomarev, I.E., Gafiatulina, N.K., Zritineva, E.I., Kasyanov, V.V., Bahutashyili, T.V., and Ponomarev, P.A. (2019). The influence of the social justice crisis on social health and spiritual security of young students (a case study of the south of Russia). International Journal of Applied Exercise Physiology, 8(2), 250-257.

34. Responsibility and influence. (2017). Retrieved from https://www.levada.ru/2017/11/13/17013/print/.

35. Schatz, R.T., Staub, E., and Lavine, H. (1999). On the Varieties of National Attachment: Blind versus Constructive Patriotism. Political Psychology, 20(1), 151-174. https://doi.org/10.1111/0162-895X.00140

36. Shakhbanova, M.M., Kasyanov, V.V., Gafiatulina, N.Kh., Gluzman, I.V., Polivina, M.A., Gnatyuk, M.A., and Ramazanov, R.O. (2019). The Role of Trust in the Formation of Ethnic Tolerance and Social Health in the Modern Russian Society. Revista Inclusiones, 6(2), 296-305. 
37. Shevchenko, O.M., and Vagina, V.O. (2017). Civil patriotism as an idea of youth consolidation in the south of Russia: specifics and difficulties of formation. Humanitarian of the South of Russia, 3, 300-308.

38. Shulga, M.M., and Kuznetsov, D.O. (2014). Youth Citizenship: Positive Practices and Risks. Bulletin of the North Caucasus Federal University, 4, 306-310.

39. Vereshchagina, A.V. (2018). Why is patriotism in the south of Russia lacking in citizenship (based on a sociological study)?Historical and socio-educational thought, 10(2), 342-354. https://doi.org/10.17748/20759908-2018-10-5/2-54-64

40. Vereshchagina, A.V., and Gafiatulina, N.Kh. (2016). Successful childhood as a basis for the social health of young generations: indicators of the sociological dimension. Engineering Bulletin of the Don, 1(40). Retrieved from http:// ivdon.ru/ru/magazine/archive/n1y 2016/3527.

41. Volkov, Yu.G., Lubsky, A.V., Kovalev, V.V., and Shevchenko, O.M. (2018a). Civil organizations and civil institutional practices in the regional communities in the South of Russia. Revista Publicando, 18(2), 115-124.

42. Volkov, Yu.G., Vereshchagina, A.V., and Lubsky, A.V. (2018b). Patriotism in Local Communities of South Russia. Modern Journal of Language Teaching Methods, 8(9), 139-146.

43. Volkov, Y. G., Vereshchagina, A. V., Lubsky, A. V., Gubarev, I. V., \& Vagina, V. O. (2018). Patriotism as the subject of discursive practices in Russia. International Journal of Engineering \& Technology, 7(2.13), 51-55. https://doi.org/10.14419/ijet.v7i2.13.11597

44. Wang, Z. (2008). National humiliation, history education, and the politics of historical memory: Patriotic education campaign in China. International Studies Quarterly, 52(4), 783-806. https://doi.org/10.1111/j.14682478.2008.00526.x

45. Williams, R. L., Foster, L. N., \& Krohn, K. R. (2008). Relationship of patriotism measures to critical thinking and emphasis on civil liberties versus national security. Analyses of Social Issues and Public Policy, 8(1), 139156. https://doi.org/10.1111/j.1530-2415.2008.00165.x 